\title{
TEKNOLOJI, SANAT VE GERÇEK
}

TECHNOLOGY, ART AND THE REAL

\section{ANKARA UNIVERSITY JOURNAL OF SOCIAL SCIENCES}

10.33537/sobild.2021.12.2.9

\section{Makale Bilgisi}

Gönderildiği tarih: Kabul edildiği tarih: Yayinlanma tarihi:

24.04.2021 17.06.2021 30.06.2021

\section{Article Info}

Date submitted: Date accepted: Date published:

\section{Anahtar sözcükler}

Bireysellik ve sanat; Kurumsal eleştiri; Nesnesiz sanat; Çokluk; Çăgdaş sanat

\section{Keywords}

Individuality and art; Institutional criticism; Art without object; Multitude; Contemporary art

\section{$\ddot{O} z$}

Makalede akull makinelerin ivmelenen gelișimi ile beliren insansonrası durumda sanat ve gerçek ilişkisinin çağdaş formu ile yeniden söz konusu olduğu düşüncesi konu edilerek incelenmektedir. Bilissel Teknolojiler, Robot Teknolojileri, Yapay Zekâ ve akıllı cihazların bedenin içine sızması, akıllı teknolojiler ve bu teknolojilerin açtığ ortamlarda yaşanan paylaşımlar gerçek ile var olan ilișkimizin konvansiyonel kabullerden farklılaștığ bir döneme girdiğimizi gündeme getirmektedir. Sanat ve gerçek ilișkisi de bu gelișime paralel olarak yeniden șekillenmekte, sanat sembolik anlatıdan çıkarak gerçeğin alanına geçmektedir. Bireyselleşen ve bağımsızlaşan sanatın alan değiştirmekte ve böylelikle tüm yalınlığ ile yaşamin gerçekliğini esas almakta olduğu makalede incelenerek çözümlenmektedir.

\section{Abstract}

The article deals with the notion that the relationship between art and reality, with its contemporary form, comes to the fore in the posthuman situation that emerged with the accelerated development of smart devices. Cognitive Technologies, Robotic Technologies, Artificial Intelligence and Smart Technologies and the sharing in the environments created by these technologies bring to the agenda that we have entered a period where our existing relationship with reality differs from conventional acceptances. The relationship between art and reality is also being reshaped in parallel with this development and Art tends to move from symbolic narrative to the realm of reality. It is analyzed within the framework of this article that art, which has become individualized and independent, tends to change the field, and thus bases on the reality of life with all its simplicity. 


\section{Giriş}

"Kolektif emek tarafindan inşa edilmiş, yeniden inşa edilmiş, yeniden biçimlendirilmiş bir gerçeklik, yapay, soyut bir boyut, her şeyi, ruhu ve bedeni, yaşamı ve ölümü istila etmiş ve her şeyin ötesinde soyut emeğin art arda birikimiyle bizzat doğanin yerini almış genel bir belirlenim" (Negri, 2013: 48)

İnsan, hakikat sonrası (post-truth) çağa gelinen süreçte kendi yarattığı gerçekliği yerkürenin gerçekliği olarak kavrayarak yaşamıştır. Doğanın gerçeğini göz ardı ederek yaşanan kurgu kendi gerçekliğini tek mümkün gerçeklik olarak dayatmış ve yaşam bu gerçeklik içinde şekillenir olmuştur. İçinde yaşadığımız toplumsallık, gerçeklik veya Jacques Lacan'ın terminolojisinde yer aldığı şekli ile simgesel sistem insanı ve kültürü kapsayan, doğa ve gerçekten bir başka gerçekliğin yaşamı perdelediği belirlenimini anlatmaktadır.

Teknolojik bir varlık olarak içinde bedenlendiğimiz bu durum ne kadar ironiktir ki yine geliştirilen teknolojik kültür sayesinde istikrarsızlaşmaktadır. Teknolojik kültürün gelişimi gerçeğin çizgisine dönüşü mümkün kılmaktadır. Gerçeğin bünyesinde inşa ettiğimiz bu kallavi yapı içinde yaşadığımız sanallık insan-sonrası durumda sorgulanabilir olmuştur. $\mathrm{Bu}$ sorgulama neticesinde insan bakışını bir başka açıya, yani retinanın önünde ve arkasında olana değil ama yerküreyi bir bütün olan kavrayabildiği bilişsel bakış açısına taşımaktadır. Gelişen teknolojiler çağdaşlığın göstergesi olan bilişsel bakış açısına veya diğer bir deyişle küresel ekolojik farkındalığın gelişmesine imkân sunmaktadır. Teknolojik kültür simgesel perdelemeyi bozarak gerçek olana yakınlaşan, doğal ve çoklu oluşuma evrilen çağdaş sosyolojiye zemin hazirlamaktadir.

Simgesel Sistem, bu ihtişamlı yapı içerisinde, yaşamın merkezine her şeyin ölçütü olarak insanı (antropos) koymaktadır. Gelgelelim gerçekte yaşamın merkezinde yerkürenin doğası vardır ve bu doğa çoklu bir işleyiş temelinde oluşagelmiştir. Bu çatışma insanın hammadde olarak gördüğü doğa ile mücadelesine yol açmış çokluğun karşısına nafile bir çaba ile insani yapılanma konulmaya çalışılmıştır. Modern dönem insani gerçekliğin doğayı alt etme girişiminin en yoğun yaşandığı süreç olmuştur. Maddi olmayan emeğe (kas emeğinden çıkarak zihinsel faaliyete) yönelen insanın özellikle teknolojik platformlarda bireyselliği çağdaş sosyolojik varlık olarak içselleştiriyor olması modern sonrası dönemde gerçek ile kurduğu ilişkiyi de gözden geçirme gereksinimini beraberinde getirmiştir. Ekolojik farkındalık ve yerkürenin bütünsel (monist) olarak kavranış1 zihinsel faaliyete yönelen çağdaş bireyin rasyonalitesinin getirisi olmaktadir.

Neo Marksist yazarlar Michael Hardt ve Antonio Negri ile Paolo Virno'nun, Antik Yunan maddecileri ve 'Baruch Spinoza'nın 'multitude' öğretisinden aldıkları temel ile kavramsallaştırdıkları 'çokluk', rasyonel ve bireysel bakış yeteneğinin bir çıktısı olarak anlam bulmaktadır. Çokluk bireysel olanın tümel olana ulaştığı doğal ve demokratik bir oluşumdur. Çokluk küresel iktisadi, siyasi ve sanat sistemleri dahil her ölçekte yerleșik iktidar yapılanmalarının yalpalamasina neden olmaktadır. Günümüzde yap1 her ne kadar katılığını ve heybetini koruyor olsa da biz eğilime ve bu eğilimin önümüzde açtığı yola baktığımızda görünür olan bireysel ve bağımsız paylaşımların giderek yaygınlaştığı çoklu alana geçiyor olduğumuzdur.

Çağdaş yaşamda bireysel ve bağımsız paylaşımların, gerçek veya dijital ortamlarda, siyasi ve ekonomik birçok alanda, iktidar karşıtı güç olarak beden buldukları kripto varlıklara dönüştüğüne şahit olmaktayız. 'Reddit' ve benzeri birçok sosyal medya platformu böylesi paylaşımlar için alan açmaktadır. Bir parçası olduğumuz doğanın tek gerçeği olan çokluk akıllı cihazların ve dijital ortamların düzlüğünde yeniden karşımıza çıkmaktadır. 'Thomas Hobbes'un birliğin medeniliği karşısında ilkellik olarak gördüğü çokluk, ne kadar ironiktir ki ileri teknolojik ürünlerin işleyişinde tekrar karşımıza çıkmaktadır.

$\mathrm{Bu}$ gelişim gözlendiğinde, teknolojik oyuncaklar ile bir festivale dönüştürülerek bizlere çağdaş sanat olarak sunulan yüksek bütçeli prodüksiyonların 1şıltısına bulaşmayan bir başka hareketlenmenin oluşmakta olduğunu söyleyebiliriz. Uzunca bir süredir kendi gerçekliğini süslemek ile meşgul olan sanatın da tüm bu gelişmelere paralel olarak alan değiştirmekte olduğunun altı çizilmelidir. Bu makale bahsi edilen alan değişimini çözümlemeyi amaçlamaktadır.

\section{Alan Değişimi}

Jean Baudrillard simülasyon ve simülakrlar ile çevrelenmiş bir yaşamdan bahsederken, kendi gerçekliği mevcut gerçeği kaplayacak şekilde yayılan istilacı bir üretimin yaşama şekil veriyor oluşunu tarif ediyordu. Dilin ve kentin egemenliğini eline geçiren görsel ve işitsel medya alaycı bir tonla gerçekliğin şimdi ve burada gösterilenden ibaret olduğu yanılsamasını bugün çok daha yoğun olarak empoze etmektedir. Kısa bir süre önce coğrafyanın yerine geçen haritanın yerine şimdi de dijital cihazlar geçiyor olmaktadır. Bu kurgunun içinde insan da başkalaşmakta, varlığını her geçen gün daha da yoğun olarak dijital ortamlarda şekillendirmektedir. Ak1llı cihazların gerçekliği insanın geleceğine şekil vermektedir çünkü insan kültür ile oluşur ve günümüz akıllı cihaz kültürü kendi öznesi ile kaynaşmakta, onu yaratmaktadır. Gelgelelim bu trans-hümanist gidişatın bir alan değişimi olduğunu söylemek çok doğru olmayacaktır çünkü insan-merkezci süreç tam da böylesi bir birleşim ile aynı doğrultuyu işaret etmektedir. Çokluk ve Antroposantrik yapı birbirine değmeyen farklı iki alandır. Çokluk, doğa ve gerçek olan işleyiştir ve bu sebeple antroposantrizm çokluğu perdeleyemez. Öyleyse bir alan değişiminden bahsetmek için insan-merkezci gelişimin dışında kalana geçiş eğilimine vurgu yapmamız doğru olacaktır. 
Çizmeye çalıştığım bu çerçevede alan değişimini 'heterodoksi'nin belirlemekte olduğunu söylememiz gerekir. Ana akımın dışarıda bıraktığı alanlar, çoklu paylaşımların gerçekleşmesi için mükemmel bir platform olmaktadır. Çünkü akıma dahil olmamak kurgusal alandan da çıkmak anlamına gelmektedir. Anonim paylaşımların doğallığı, küresel iktidar yapılanmalarının gerçekliğinden başka bir alanın temellerini atmaktadır ve beliren bu alana geçiş bireysellik ve bağımsızlık ile mümkün olmaktadır. Jenerik ve sembolik üretimleri bir yana bırakan, sanat dünyasının iktidar yapılanmasından bağımsızlaşmış paylaşımların yarattığı çokluk ile çağdaş sanat da belirmekte olan bu alana göç etmektedir.

\begin{abstract}
"Bereketli ve clvıl cıvıl bir hayatın bir hayatın hüküm sürdüğ̈̈ her ortam müze duvarları arasına kapatıldiğı anda - çelişki bu ya - donup kalıyor. De Certeau'ya göre kültür henüz meşru görülmediği sinırlarda tomurcuklanıyor. Yaratıctliğn uğultusu ise tanımlanması güç bir birikimden çıkıyor. O halde De Certeau devaml hareket halinde olan, kendini bir an gösteren ve sonra aniden yok olan bir saçlmadan söz ediyor." (Gielen, 2016: 26)
\end{abstract}

Sanat uzunca bir süredir kendi gerçekliğini oluşturmak ile meşguldür. Sanatçının yaratım gücü ile sanat dünyasının anlatı oluşturma kabiliyeti ve kurumsal etki ile yaratılan hayali bir evren sanat edimi olarak küresel hakimiyet edinmiştir. Platonun da vizyon ve hayal gücünün ürünlerinin yalnızca sahte taklitler sunabileceğine inanması sebebiyle gerçekten sapmak olarak yorumladığı ve olumsuzladığı bu durum modern dönemin egemen sanat anlayışı olarak karşımıza çıkmaktadır. 20. Yüzyılda her ne kadar sanatın gerçekliği ile yaşamın gerçeğini birleştirmeyi amaçlayan Fluxus ve benzeri hareketleri gözlemlemiş olsak da sanat dünyası bu dönemde egemenliğini sanatın kurgulanmış gerçekliğine dayandırmıştır. Özellikle Neoliberal politikalar sanatı tüketilebilir kültüre dönüştürürken, sponsorların kontrolünde sanat izole bir prodüksiyon olarak seyirciye sergilediği görsel şölen ile değerlendirilir olmuştur.

Sanatın ağdalı bir dille görselleştirdiği yaratımlar, dijital manipülasyonlar veya multimedya gösterilerinden farklı bir alanda gelişen ve canlılığın tüm gerçekliği ile sergilendiği bir başka sanat anlayışı yeni yeni görünür olmaktadır. Werner Herzog'un “Aile Saadeti Ltd.” filmi bu sanat anlayışını çözümlemek için iyi bir örnek olabilir. Filmi bir belgesel olarak yorumlamak doğru olmayacaktır çünkü film bize rapor ettiği veya belgelediği veya kameranın tanıklık etmesi istenilen bir olguyu aktarmaz. Aksine filmde bir öykü sübjektif öğeler ile anlatılır ve yaşananlar karşısında bireylerin varlığı, kararları, sözleri ve tavırları korunmaktadır. Herzog bunu hiç bilmediği bir dilde, Japoncada, oyuncuların doğaçlama yapmasını isteyerek başarmıştır. Filmin baş oyuncularından olan Ishii Yuichi kendi şirketindeki gerçek rolünü oynamaktadır ve oyuncu kimliği ile gerçek kimliği arasındaki sınır çok belirli değildir. Film kurgusal piyesler ile tatmin edilmeye çalışılan insanların gerçek hikayesini anlatmaktadır.

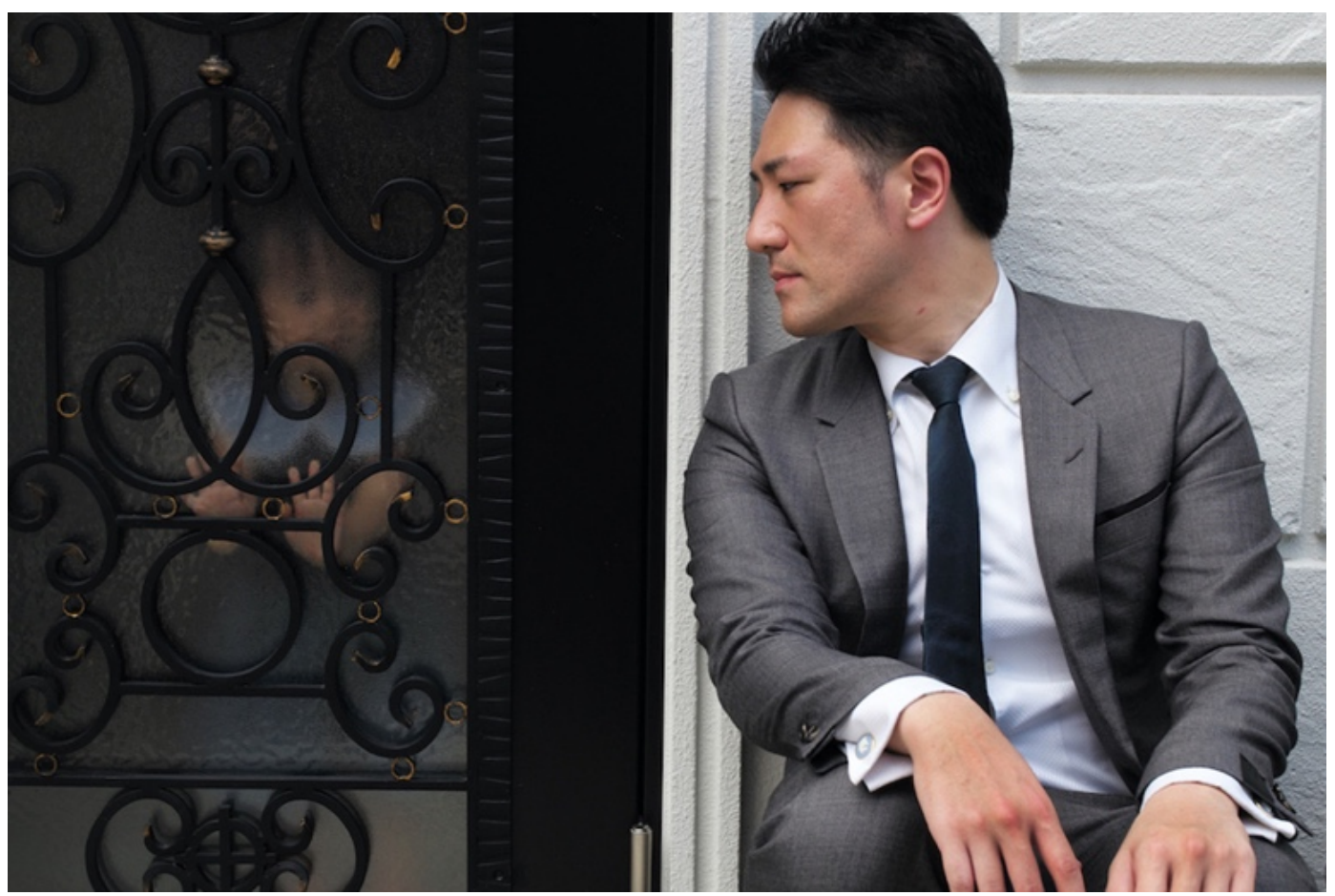

Görsel 1: Yönetmen Werner Herzog, Aile Saadeti Ltd. (Family Romance LLC.) Filmden Bir kesit, 2019.

$\mathrm{Bu}$ haliyle film bireysel öğelerin birleşiminden oluşmaktadır. Her oyuncu varlığını, girdikleri rollere bir süreliğine devretmek yerine kişisel olarak deneyimledikleri ve hatta kameranın kayıtta olduğu o an tecrübe ettikleri haliyle korumaktadır. Jenerik bir duygu durumu veya tavir Herzog'un sinematografisinde kullanılan kesintisiz kamera kayıtları ve benzeri teknikler neticesinde filme alınmamıştır. Film anlık olarak 
kameranın yakaladığı bireysel deneyimleri ve karşılaşmaları Neo-Brechtyen bir yaklaşımla beyaz perdeye taşımıştır. Filmin bireysel yaşam kesitlerini görüntülemesi gerçeği yakalaması ve göstermesi anlamina gelmektedir.

\section{Bireysellik ve Sanat}

Sanat ideal olanı sunmaktan sıyrıldığı yıllarda, özellikle fotoğraf kamerasının icadı ile realist ve natüralist anlayışın etkisine girmişti. Natüralistler doğayı yüzyıllardır idealize edildiği gibi değil ama gerçeğe en yakın haliyle, bir bilim insanı edasıyla araştırarak görselleştirmeye çalışmışlardı. Romantikler, 'Antropos'a özgü olanı görsel sanatlara taşıyarak natüralist yaklaşımın sonunu ve modern dönemin de başlangıcını resmetmişlerdi. Romantizm sanatçının filtresinden geçmiş sunumları yani gerçekliği insanileştiren yapıtları sanatın merkezine koymuştu. Sembolizm ve sonrasında ekspresyonizm, insani gerçekliğe rüyaları, hayal gücünü ve duygu durumlarını ekleyerek zenginleştirmişti. 20. Yüzyılın başlarında gördüğümüz avangart akımlardan 'Dada' nın anti-art tavrı, Süprematizm, Fütürist Serratalar ve Varyete Tiyatroları ile Duchampyen bozucu eylemler ve Hazır Nesneler (Ready-made) bu görsel zenginliğin hayali dünyasından ayrışmayı esas almışlard1. Kübistler ve sürrealistler yaparken, sanatın doğasını sorgulayan yapıbozumcular ve minimalistler yıkmak için uğraşıyordu. Bu iki tavrın geriliminde, özellikle 20. Yüzyılın ikinci yarısına gelindiğinde gördüğümüz, Neo-liberal politikaların da etkisiyle, sanatın kurgu zenginliğinin gösterdiği yolu ana akım haline getirmesiydi.

Tüm bu gidişat içerisinde yeni medya türevlerinin sanat alanına girissi ile 'bireysellik' teknolojik aygitların sunduğu imkanlar sayesinde daha net görünür olmaya başlad1. Bireysel olanın gerçek ile bağ kurmamıza müsaade etmesi, sanatın sınırlarının bu yönde genişletilebileceğini gösteriyordu. Herhangi birisinin hikayesi değil ama o an orada olan o kişinin spesifik tavrı en soğuk gerçekliği ile sanata taşınıyordu. Bireysel olana tanıklık gerçek olana dokunmak anlamına geliyordu. Bu noktada bireyselliği birçok yeni medya sanat yapıtının ortaya koyduğu danışıklı döğüşten ayırmak gerekir. Bireysellik seyirci ve sanatçının ortak üreticiye dönüştürüldüğü formüle edilmiş bir senaryo değil ama sonunun nereye açılacağı bilinmeyen karşılaşmalar, paylaşımlar, davranışlar, etkileşimler yani kısaca hayatın kendisinin bireylerin deneyimlediği şekli ile sanata taşındığı bağımsız çalışmalar olarak anlaşılmalıdır.

Birey olmak sanat bir yana dursun hayatın akışı içerisinde dahi çok mümkün değildir. Toplumsallık maske takmayı gerektirir ve maskenin altına gizlediğimiz bizler ancak gerçeklik örüntüsünün kırıldığı anlarda varlığımızı iddia ederiz. Sanat tam da tekinliğin tekdüzeliğini bozan bu kırılmaları yakalamalıdır. Ben Kinmont'un rastlantısal karşılaşmalarını bireysel paylaşımların gözlemlendiği deneyler olarak okuyabiliriz. Kinmont, bu projesinde sokakta rast geldiği kişilere bulaşıklarını yıkamayı teklif ediyordu ve böylelikle kabul edenlerin evlerinde bulaşık yıkarken sohbet etme firsat1 da buluyordu. $\mathrm{Bu}$ deneyimlerin her biri özgün birliktelikler, diğer bir deyişle o ana özel paylaşılan bir zaman diliminden ibarettiler. Her karşılaşma ve birliktelik önceden planlanmış hiçbir hesaba uymuyordu, tamamı bireye özel deneyimlerdi ve aktarmak veya rapor etmek hangi sanat medyumunu kullanırsanız kullanın eksik kalyyordu. Kinmont bu sebeple bir gösteri yapmaktan ziyade sanatını anlık yaşam parçaları olarak belirliyor ve sunuyordu. Bulaşık yıkamak sadece bir bahaneydi, esas olan Kinmont'un karşılaştı̆̆ kişiler ile kısa süreli birliktelikler yaşamasıydı ve bu durum tamamiyla bireysel bir etkinlikti çünkü belge olarak kameraya çekecek veya videoya kaydedecek hiç kimse de olmadığından gösterisel hiçbir öğe çalışmanın içine sızamıyor, önceden planlanmış hiçbir şey sahnelenmiyordu. 


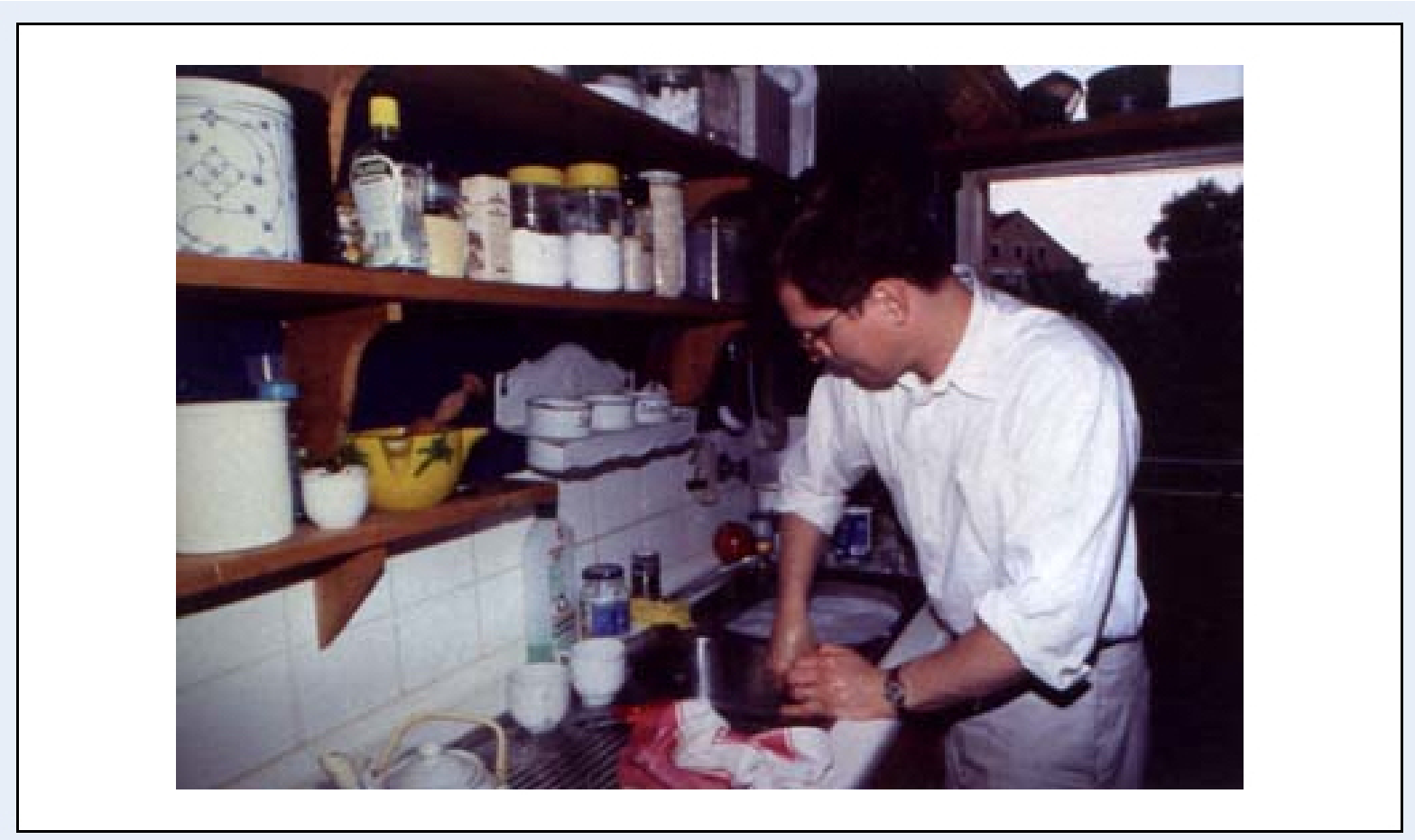

\section{Kinmont washing dishes in a participant's home, May 1994}

Görsel 2: Ben Kinmont, 'Kirli Bulaşıklarını Yıkayacağım' (I Will Wash Your Dirty Dishes), Ben Kinmont’un Bir Katılımcının Evinde Bulaşık Yıkarken Çekilen Anonim Fotoğrafı, Performans - Davranış Modeli, 1994.

Bireysel olanın cazibesi sanatı belgeleme ve müzeleme çabasıyla bir anda buharlaşmaktadır çünkü planlanan her editoryal yaklassım bireyselliği bozar. Bir fotoğrafın içerisine özenle yerleştirilmiş bir 'punctum' olamayacağ1 gibi bireysel deneyim de belgelenemez. Tarihsel örneklerde gördüğümüz ham görüntü yakalama ve kaydetme deneyleri, özellikle Andy Warhol'un 'verité' sineması yakalamak için uğraştığ şeyi tam da o çaba içinde oluşu ile kaçırmıştır. Gerçek olanı yakalamak belki ancak izinsiz çekilmiş bir fotoğraf veya ortam kamerası ile mümkün olabilir. Sanat yapma çabasından uzaklaşıldıkça ancak gerçek karşılaşmalara ve yaşamın akışına dokunulabilir. Bireysel deneyim ve sanat bu bağlamda bir araya gelmesi zor olgulardır fakat çağdaş sanatçının bu zorluğun üstesinden gelmesi akıllı cihazların kullanımı ve dijital ortamların yaygınlaşması ile giderek kolaylaşmaktadır.

Sembolik, alegorik, imgesel ve temsili anlatımlar gerçeği ve bireyselliği iletmekten ziyade kendi varlıklarını gerçeğin yerine koyarlar. Gerçek olanın sanat alanına taşınması dolayısıyla bu yöntemlerin yetkin kullanımıyla mümkün olamaz. Makalenin en başından itibaren işaret edilmeye çalışılan konu da zaten sanatın keşfettiği en etkili yöntemlerin terk edilerek sanatın gerçekliği yerine en yalın haliyle gerçeğin geçiyor olduğudur. Çünkü 'gerçek' varlığını artık delege etmek zorunda, yani bir sembol ile iletmek mecburiyetinde değildir.

Bireysel deneyimler dijital ortamlara taşındıkça veya akıllı cihazların yaygın kullanımı ile paylaşım ağlarının yarattığ 1 ortamlarda gerçekleşen birliktelikler giderek daha çok canlılık sergilemeye başladıkça sanat, belgelemeye ihtiyaç duymadan, bireysel olan karşılaşmaları konu ediniyor olmaktadır. Kısacası ileri teknolojiler sanatçıya, temsili olana gerek duymadan asıl olanı sunma fırsatını vermektedir. Küresel ölçeğe yayılan hacmi ile gerek sanatçıların gerekse katılımcıların ilgi alanı böylesi platformlarda görülen ve yaşanan bireysel buluşmalara, karşılaşmalara ve etkileşimlere kaymaktadir.

Gerçekliğin gün geçtikçe artan katılığına karşı dijital ortamların aynı hızla canlanıyor olduğunu görmekteyiz. Böylesi teknolojik ortamların canlılık göstergesi bireysellik ve bağımsızlıktır. Sanatın bireysel olması kadar bağımsız olması da gerçek olan ile ilişkilendirilmesi açısından gereklidir. Dijital teknoloji ve akıllı cihazlar 'sanat iktidarına' bağlı olmayı gerektirmeyen platformlarda paylaşımı mümkün kılmaktadırlar ve sanat dijital ortamlara yöneldikçe müzeler, galeriler ve benzeri kurumların denetiminden bağımsızlaşmaktadır.

\section{Bağımsılık ve Sanat}

Bağımsızlık hali George Dickie'nin tabiriyle 'Kurumsal Etki' veya Arthur Danto'nun deyimiyle 'Sanat Dünyası' etkisinden bağımsızlaşmak olarak anlaşılmalıdır. Elbette bu durumda sanat dünyasının sınırı veya kurumların kimlerden ibaret olduğunun netleştirilmesi gerekir. Sanat eserinin oluşumuna etki eden unsurlar yani sanatç1, seyirci, alıc1, satıc1, eleştirmen, akademisyen ve benzeri kişiler ile galeriler, müzeler, akademiler ve benzeri tüm kurumlar neyin sanat olduğunun belirlendiği bir sistemin parçasını oluştururlar. Sanat kurumlar etkisinden bağımsızlaştığı durumda ancak 
siyaset alanından çıkarak politik olmayan özgür işleyiş firsatı bulabilir.

Sanat siyasetine bulaşmayan çalışmalar ancak bağımsız oldukları durumlarda gerçekleştirilebilirler. Bir set, kamera kayit sistemi, dekor veya sinema salonu ve televizyon kanalına bağlı kalmadan çekildiğinde ve paylaşıldığında bir film sanat dünyasının iktidar yapilanmasına meydan okuyabilir. Meydan okuma tüm bu hantal kurumları pas geçerek gerçekleşir. Reha Erdemin 2021 tarihli filmi 'seni buldum ya' bu durumu anlatan doğru bir örnek olacaktır. Film 'zoom' online konferans programının kayıt özelliğini kullanılarak çekilmiştir, set kullanılmamıştır, oyuncuların kendi evleri yani gerçek mekanlar filmin mekanını oluşturur. Dekor ve kostüm gereksinimi de olmamıştır. Bunlar ve tüm benzeri sebepler ile film gişe hasılatına bağımlı kalmamıştır. Seyirciyle buluşmak da zor değildir çünkü film online ortamlarda izleyicilere açılmıştır. Film bu haliyle birçok yerleşik kurumun bağımlılığından sıyrılmış, kendi konusu üzerine odaklanmış ve böylelikle amaç en yalın haliyle hikâyeyi anlatmak olmuştur.
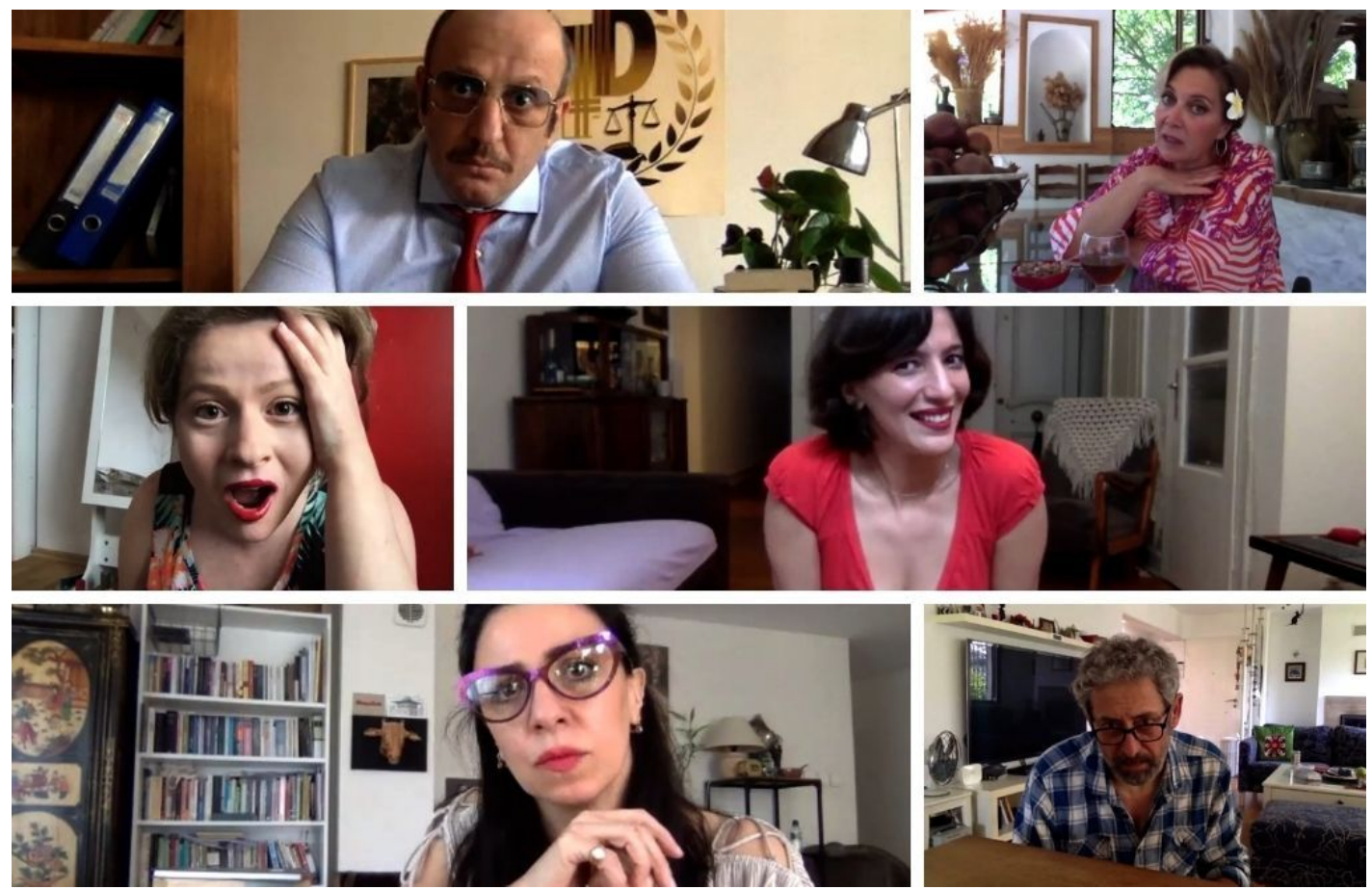

Görsel 3: Yönetmen Reha Erdem, 'Seni Buldum Ya', Uzun Metrajlı Film, Filmden Bir Kesit, 2021.

Kurumların sanatçı üzerindeki iktidarı, teknolojik aygitların görece ucuzlayarak genel kullanıma yayılması ile sarsılmakta ve sanat giderek özgürleşmektedir. Üretim ve paylaşıma yönelik geliştirilen teknolojik enstrümanların ve akıllı cihazların kolay ulaşılabilir olması sanat dünyasının kontrolüne sığmayan bir hareketliliğe tanık olmamızı beraberinde getirmiştir. Online sanat paylaşımları kurumları büyük ölçüde devre dışı bırakmaktadır ve bağımsızlaşan sanat çoklu söyleme açılan bir edime dönüşmektedir.

\section{Çokluk ve Sanat}

Çokluk altı çizilmesi gereken bir olgudur. Çoğu zaman ilkellik ve ilksellik ile ilişkilendirilse de çokluk, gerçek ile olan doğal ilişkisi sebebiyle bireysel ve bağımsız sanat ediminin mütemadiyen ulaştığı işleyiş olmaktadır. Ucu açık paylaşımlar 'form' unda geliştirilen sanat politik olarak değil özünde gerçektir. Sanatın çokluk ile karşılıklı bir oluş içindeki varlığı, Hal Foster'ın 'Gerçeğin Geri Dönüşü’ isimli kitabında incelediği gerçek ve sanat ilişkisinden farklı bir okuma gerektirmektedir. Foster, gelenekselden kopamayan bir yaklaşımla, gerçeği sanat yapıtının içinde aramaktadır veya diğer bir deyişle sanat yapıtının kurgusunun gerçeği de sunabileceği düşüncesini birçok sanatçı örneğinde inceleyerek çözümlemektedir. 'Lacan'c1 öğretide gördüğümüz 'imge perde' kavramına gönderme yaparak, bir yapıt üzerinde perdenin aralandığı durumları işaretlemeye çalışan Foster, gerçeğin bir temsil (reprezantatif bir çalışma, eser, yapit) üzerinde görünür olduğu anlarda (gerçek olanın) geri döndüğü düşüncesini ileri sürmektedir (bkz. Foster, 1996: 194). Gelgelelim bahsi geçen durumda yapitın nesnelliğinde görünür olan, mükemmel bir politika ürününden başkası değildir. Perdenin arkasından sızan, sanatçının tam da gerçeği sunmak istemiyle kurguladığı ve oradan sızması için yapita yerleştirdiği bir başka yanılsamadır. Bu nedenle Foster'ın savını dayandırdığı Hiper-Realizm, 'Appropriation Art' (Temellük Sanat1) ve 'Abject Art' (İğrenç Sanatı) örnekleri gerçek olanı sembolik olarak anlatmanın ötesine geçemez.

Bir sanat eseri üzerinde gerçek ile ilişki kurabiliyor olmamız, ancak sanat yapıtının nesnelliğinden, kurum ve toplum etkisinden bağımsızlaşmak ile mümkün olabilir. Bu sebeple teknolojik imkanları kullanan sanatçı ancak çoklu paylaşım ortamlarında gerçek olanı sanatına taşıyabilir veya sanat tam da bu edimin kendisi olarak görülebilir. Michael Mandiberg'in yeni medya çalışması 
'Gerçek Maliyetler' in (The Real Costs; 2006, e-ticaret, seyahat ve navigasyon web sitelerindeki karbon ayak izlerini hesaplayan, uçuşların, kiralık arabaların ve eticaret kargolarının karbon emisyonlarını gösteren bir web tarayıcısı eklentisidir) internet sitesi aracılığıyla seyahat ve ticaret araçlarının atmosfere bıraktığ karbon salınım miktarlarını yani bu araçların parasal maliyeti yerine ekolojik sisteme olan maliyetini gösteriyor olması, gerçeği olduğu gibi sunması anlamına gelir. Mandiberg herhangi bir yorum eklemeden veya imgesel anlatıma başvurmadan sadece miktar bilgisi paylaşarak gerçek maliyetin be olduğu hakkında fikir yürütmemizi önermektedir. $\mathrm{Bu}$ örnek sanatın sembolik olarak sergilenenden farklı bir alana taşınmakta olduğunu göstermektedir ve bu alanda da kurgunun yerini gerçek, bilgi olarak almaktadır.

\section{RèàlCosts \\ nome \\ screen shots \\ What is Real Costs?}

\section{Real Costs}

is a Firefox plug-in that inserts emissions data into travel related e-commerce websites. The first version adds $\mathrm{CO} 2$ emissions information to airfare websites such as Orbitz.com, United.com, Delta.com, etc. Following versions will work with car directions, car rental, and shipping websites. Think of it like the nutritional information labeling on the back of food... except for emissions.

\section{Download Now :}

\author{
Download Current Real Costs Firefox Plugin \\ For Developers : \\ Current Greasemonkey Development Snapshot: \\ Requires Greasemonkey \\ This is like the source code for the plugin \\ eveloper? Get in touch: Michael [a] Mandiberg [*] com \\ Unsure what this is? you probably should click above. \\ Current version (vo.0.6) is beta. It works on these websites
}

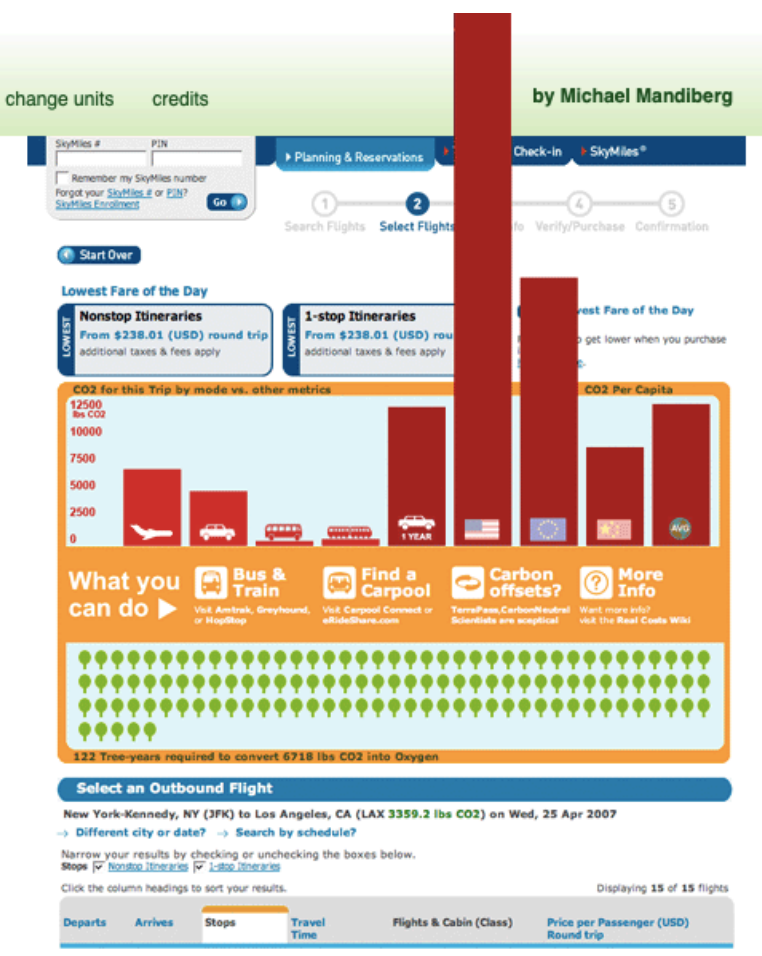

Görsel 4: Michael Mandiberg, Gerçek Maliyet (The Real Cost), Web Sitesi Eklentisi, Siteden Alınmış Bir Ekran Kesiti, 2006.

Bu noktada altı çizilmesi gereken bir başka konu daha vardır. Bağımsızlık her zaman iyicil veya güzel sanat üretimine giden bir etken değildir. Gerçek özünde fantezilerden arınmış yalınlığın kendisidir ve bu haliyle her durumda güzel olması beklenmemelidir. Gerçek olmak ve güzel olmak iki ayrı durum olarak sanatta yer edinmiştir ve aralarındaki geçişkenlik zorunlu değil rastlantısaldır. Elbette o zaman neden gerçek olanın arzulandığı sorusunu sormamız gerekir. Gerçek olan cezbedici olmak durumunda değildir, çağdaş sanatın ilgi çekmek için uğraşan görünümden uzaklaşma eğiliminde olmasının da bu sebepten kaynaklandığı düşünülebilir. Sanatın gerçek oluşu kurgudan bağımsızlaşan bireyselliğin sunumunda ve paylaşımında aranmalıdır. $\mathrm{Bu}$ sanat anlayışı rasyonel varlık olarak çağdaş insanın yaşamı anlama, çözümleme ve parçası olma halini yansıtır. Dünyayı daha iyi bir yer yapmak veya süslemek çabasından uzaklaşan bu edim, tüm gerçekliği ile yaşamı ve mekânı kavramak ile ilgilidir. Bizler bireysel ve rasyonel bir varlık olarak çağdaşlaştıkça sanat alımlı (güzel) görünse de görünmese de gerçeğe yönelecektir tıpkı yaşamın (toplumsallı̆̆ın) kendisi gibi.
Tüm bu anlatılanlara ek olarak, Postmodernist bağlamda kurulan gerçek ve sanat ilişkisinin de aynı şekilde sorunlu olduğunu söylememiz doğru olacaktır. Postmodernist sanat pratikleri kurgudan bağımsılaşmak yerine kendi kurgularını yaratmaya çalışmışlardır. Modernizmin görselleştirdiği güzellik ve gerçeklik olgularının aksi hali de yani 'Abject Sanat' pratiğinde gördüğümüz gibi iticiliği malzeme ederek ilgi çekme çabasındaki gerçeklik de esasında oyunun bir parçasıdır. 'Abject Sanat' iğrençliği güzelleştiren ve sanat olarak belirleyen bir tavır olarak sanat söyleminde yerini almıştır. Modern sonrası dönem sanat edimi gerçek ile ilişkisini modern dönem sanatını yıkarak veya parodileştirerek kurmaya çalışmışsa da bu çaba bir süre içinde sanat yapma tavrına dönüşmüş ve eleştirdiği şeyin yerine geçmiştir. Postmodernizm bu sebeple, kurulu gerçekliğin içinde bir başka gösteri olmaktan öteye gidememiştir. 


\section{Nesnellik Sorunsalı}

Günümüz teknolojilerinin bağımsız alanlar açıyor olduğu düşüncesi ileri teknolojilerin nesnel olmayan kültür yaratma gücü ile ilişkilidir. Gerçeklik kurgusu ve inşa özellikle sanat alanında hep bir nesne üzerinden gerçekleşmiştir. Kurumsal etkiden ve sanat dünyası iktidarından bağımsızlaşma öyleyse nesnelliğin sorgulanması ve aşılması ile mümkün olabilir. Nesnesiz sanat eseri üretimi, çoğaltımı ve paylaşımı teknolojinin yarattığı dijital ortamlarda yayılmakta, bireyleri de içine katarak her geçen gün hacmini genişletmektedir.
Yeni medya sanatı fotoğraf, video, bilgisayar, internet, 1ş1k ve benzeri medyumların kullanımı ile gerçekleştirildiğinden nesnesiz sanat edimine olanak tanımaktadır. Nesne yeni medya sanatında biriciklik (uniqueness) öğesi olmaktan çıkarak bir aracı durumuna gerilemiştir. Aracılık ettiği edim ise mesajı iletmek veya salt teknolojinin kendisini olduğu gibi sunmaktır. Aracı olmasının yanı sıra yeni medya teknikleri çoğaltıma, etkileşime, paylaşıma ve küresel ölçekte yayılıma imkân tanımaktadır. Yeni medya yapitları bir nesnenin sinırlamasına tabi olmadiklarından bugün dahi müzeleştirilmeleri sorunlu hal almaktadır. Sanat kurumları bu uçarı kaçarı üretimleri nasıl müzelere veya galerilere hapsedecekleri sorununu hala çözememişlerdir.
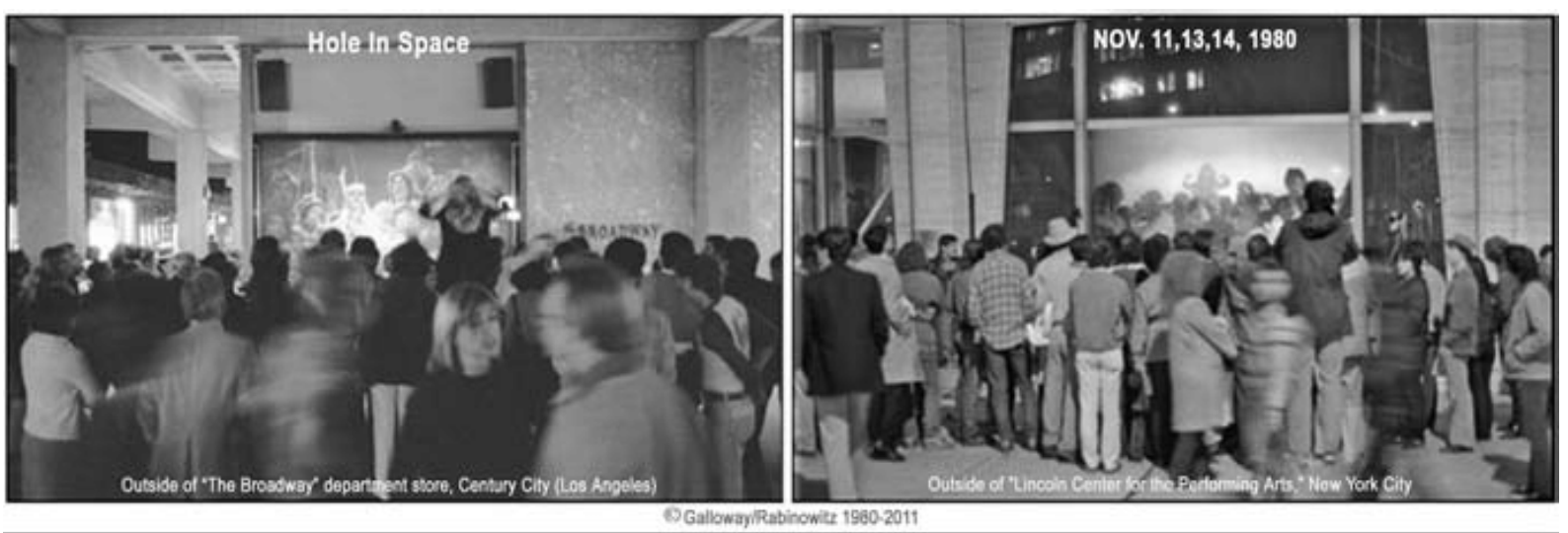

Görsel 5: Kitt Galloway ve Sherrie Rabinowitz, ‘Uzamda Delik’ (Hole In Space), Bir Topluluk İletişim Heykeli (A Public Communication Sculpture), 1980.

Kitt Galloway ve Sherrie Rabinowitz in 1980 y1lında gerçekleştirdikleri 'Uzamda Delik' isimli yeni medya çalışması müzeleştirme sorununu incelemek için uygun bir örnek olarak değerlendirilebilir. 'Uzamda Delik', farklı şehirlerde (New York ve Los Angeles), açık mekâna yerleştirilmiş iki video kamera ve iki ekran aracılığ ile kurulan görsel medya iletişimine olanak tanıyordu. Kitt Galloway ve Sherrie Rabinowitz, katılımcilara ait video kayıtlarının aynı zamanlı olarak ekranlara yansıtılması sayesinde (günümüzde kullanılan terim ile video konferans sistemi) gerçekleştirilen mikro iletişim ağını sanat eseri olarak sunuyordu. Yaratilan bu ortak alanda, farklı şehirlerdeki katılımcılar beraber şarkı söylüyor, sohbet ediyor, güncel meseleleri paylaşma imkânı buluyordu.

\section{Hank Bull'un bu çalışmayı belgeleyen video da belirttiği gibi: "Sonuçlar şaşılası, genellikle heyecan vericiydi. ... Insanlar birlikte şarkılar söylemiş, oyunlar oynamis, hatta uzaktaki akrabalariyla sohbetler etmişlerdi." (Shanken, 2009: 33)}

Böyle bir yapıtın gerçekleştirilmesi için kullanılan malzemeler, yani video kayıt cihazı, kablosuz iletişim ağı, ekran ve diğer cihazlar yapıtın oluşması için kullanılan araçlar olmaktadırlar. Yapıt ortak üretilen anlık paylaşımlar, katılım ve biraradalık üzerinde şekillenmektedir ve biçimi kişilerin geliştirdikleri davranış modelleri ile belirlenmiştir. Bu haliyle 'Uzamda Delik', nesnesinden bağımsız bir yeni medya sanat örneği olarak görülmelidir. Günümüz paylaşım platformlarının öncülü olan bu çalışma maddeye bağlı olmaması ve katılımcıların deneyimlediği her anın bir diğerinden farklı oluşu sebepleriyle sanat kurumlarının duvarları arasında kalmamıştır. Anlık, bireysel ve geçici olanın, yani tıpkı yaşam gibi olanın tecrübe edildiği bir platform olması ile akış içindeki gerçeği sanata taşımaktadır.

Bu noktada dikkat çekilmesi gereken bir diğer konu da günümüzde, çağdaş akıllı cihazların her an böylesi platformlar yaratma kapasitesi olduğudur. Anlık, gelip geçici akış içerisinde olanın sanat alanına taşınması akıllı teknolojilerin kullanımı ile kolaylaşmıştır. Fantezilerimize bulaşmamış bir sanat edimi olarak sunulan gerçek, tüm yalınlığı ve netliği ile çoklu platformlarda yerini alıyor olmaktadır. Sanatın gerçeğin alanına geçmekte olduğu sav1 gündelik paylaşımların akıllı cihazlar aracılığıyla sanat edimi ile kullanılması eğilimine dayanmaktadır.

Bunun yanında, nesnesinden bağımsızlaşan yapıtı, sanat kurumlarının kendi varlıklarını muhafaza etme amacı ile tekrar nesneye dönüştürme çabası yitik bir paradigmaya yapılan suni teneffüsü andırır. Çünkü her ne kadar bugün egemen oldukları yapı ayakta duruyor olsa da eğilim ivmelenen hızı ile bireysel ve bağımsız olana doğru akışı göstermektedir. Sanat dünyası varlığını siber ortamların çokluğuna devretmektedir. Dijital ortamların uçarı ontolojisi sanat dünyasının eril yapısına uyma zorunluluğunun üzerini çizdikçe kalıba sığmayı reddeden 
bireysel ve bağımsız çağdaş sanat edimi, sanat kurumlarının egemen olduğu toprakları aşmaktadır. Postmodern dönemde ancak sembolik olarak sorunsallaşan nesne ve üzerinde inşa edilmiş kurumlar böylelikle tam anlamıyla işlevsizleşmektedirler çünkü sanat, kurumların iktidar alanından çıkarak gerçeğin alanına geçmektedir.

\section{Walter Schels Fotoğraflarında Yakalanan Gerçek}

Gerçek kendini simgesel sistemin perdeleyemediği anlarda gayet açık olarak göstermektedir. Doğum ve ölüm bu anların en kesin olanlarıdır. Doğanın gezegendeki canlılığ1 muhafaza yöntemi olan doğum ve ölüm, yaşam döngüsünün başı ve sonu, gerçeğin en net göründüğü anlardır. Jacques Lacan öğretisinde gördüğümüz 'Gerçek Evresi' nin, yeni doğan insanoğlunun dilin egemenliğine girmesi ile yani konuşmaya başlaması ile son bulduğu anlatılmaktadır. Simgesel sistem kendi gerçekliğini dilin

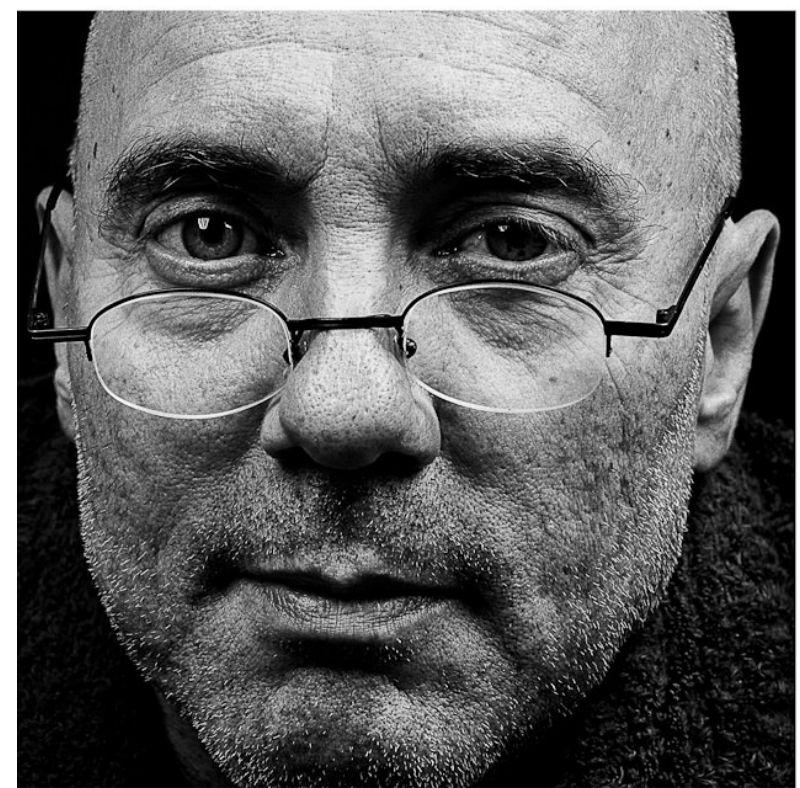

Görsel 6: Walter Schels, Ölümden Önce Yaşam (Life Before Death) Heiner Scmitz’in Portresi, Yaş: 52, İlk Portre 19 Kasım 2003, İkinci Portre 14 Aralık 2003. Portre Fotoğraf, 2003.

Schels, ölümü genel bir olgu olarak incelemeye çalışmamış ama aksine ölümü onu tecrübe eden bireyi fotoğraflayarak kişi üzerindeki görünümü ile sanat alanına aktarmıştır. Bu sebeple sanatın bireysel olana yönelimini ifade etmek için doğru bir örnek olmaktadır. Bireysel olmasının yanında simgesel bir anlatım kullanmaması ve tüm yalınlığı ile gerçeği göstermeye çalışması makale kapsamında çözümlenmeye çalışılan gerçeğin alanına yönelim savını destekleyen bir örnek olmaktadir.

\section{Sonuç}

Sanatın gerçek ile kurduğu ilişkiyi kavramak ve pratiğe dökmek sanatçıları ve düşünürleri her daim meşgul etmiştir. Kimi zaman gerçeğin temsil edildiği yöntemlere yaslanılmış kimi zaman da kendi gerçekliğini oluşturan sanat hâkim edim olarak tarihte yer edinmiştir. Gerçekliğin kurgulandığı sanat anlayışının tarih boyunca festivale dönüşen renkliliği günümüzde, teknolojinin

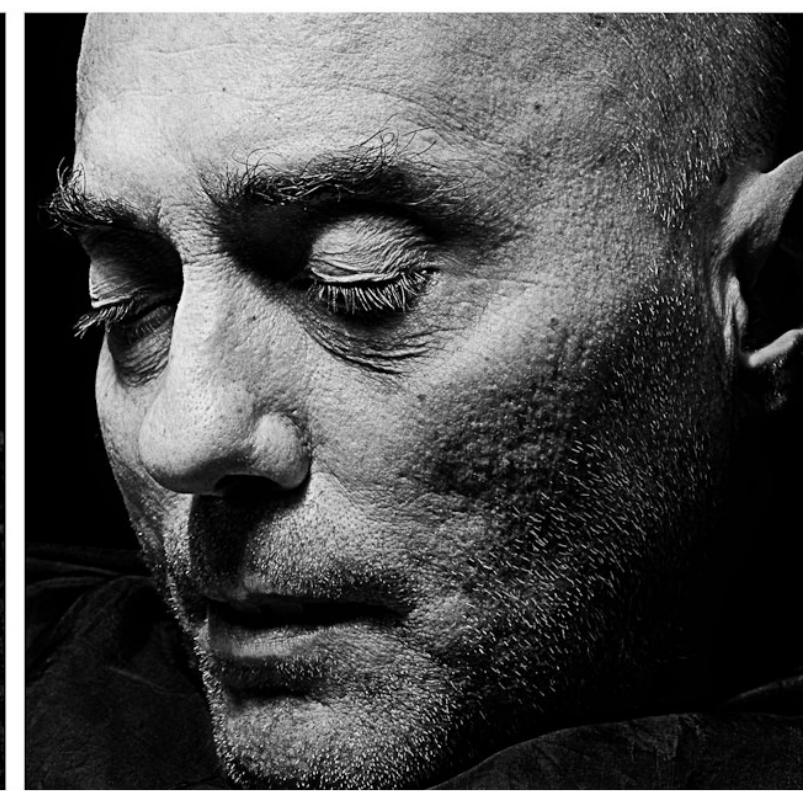

eril yapısına dayandırmaktadır öyleyse doğum anından dilin yasasına tabi olunana kadar ki süreç gerçek evresi olarak öğretide yer bulmaktadır. Tıpkı doğum gibi ölüm de simgesel sistemin egemenliğinden çıkış anlamına gelmektedir ve tüm soğukluğu ile gerçektir.

Bir gerçek parçası olarak kabul edilen ölüm birçok anlatıda (özellikle dinsel anlatılarda) simgesel sisteme yani dilin alanına dahil edilmek istenmiştir. Simgesel ve temsili anlatı ile, ölümü gerçek olduğu şekli ile değil ama sembolik olarak ifade eden çeşitli örnekler verilmiştir. Ölümün gerçeğini dolaysız yoldan yakalamak ve sanat eseri olarak sunmak için yola çıkan Walter Schels, bu amacına diri ve ölü olanı karşılaştırarak ulaşmaya çalışmıştır. Schels ölmeden hemen önce ve öldükten sonra fotoğrafladığı kişilerin portrelerini yan yana sergileyerek canlılığın yitimini gözler önüne sermektedir.

desteği ile yerini gerçeğin yalınlığına bırakmaktadır. Akıllı cihazların ve paylaşım ortamlarının açtığı alanlarda sanat, gerçeğin tüm canlılığı ile yer aldığı anlayışa doğru yönelmektedir. Uzunca bir süredir sembolik olarak ifade edilenin yerini bizzat ifade edilmeye çalışılanın kendisi artık aracısız olarak almaktadır.

Akıllı cihazların ve dijital ortamların gelişimi aracıları hem görsel hem de kurumsal anlamda aradan çıkarmaktadır. Sanat kurumlarından bağımsızlaşma ve bireysel anlık olanın paylaşıma açılması aracı olmadan gerçeğin sunulduğu sanat pratiğine açılmaktadır. İlgi alanı hayal gücünün üretimlerinden bireyin o an ve orada yaşadığının ortak deneyimine doğru kaymaktadır. Günümüz teknolojileri bu paylaşımlara uygun zemin yaratırken online ortamlarda varlığını şekillendiren çağdaş öznenin bireysel tavrı benimsemesi bu alan değişimini desteklemektedir. Rasyonel birey gerçeğin canlılı̆ını sanat olarak deneyimlemeyi ve paylaşmayı 
görsel şölenden ibaret görülen sanat anlayışına tercih etmektedir.

Elbette bu noktada bir eğilimden bahsedilmekte olduğunun altını çizmemiz gerekir. Üretimin makinelere devredildiği, bilginin kolay ulaş1labilir olduğu ve akıllı cihazlar ile çağdaş bireyin donatıldığ bu çağda, üretilmiş gerçekliğin cazibesi giderek azalmaktadır. Rasyonelliğin egemen olacağı çağa ivmelenen bir hızla girmekteyiz ve bu durum sanatın da bilişsel yaklaşıma yönelmesini beraberinde getirmektedir. Çağdaş bireyin bilişsel faaliyeti çokluk olarak anlaşılmakta, çokluk da gerçek ile ilişkilendirilmektedir.

Pragmatik aklın egemenliğine devrettiğimiz dönem sonrasında tecrübe ediyor olduğumuz ve rasyonel bir varlık olarak yerküreyi bütünselliği ile kavrayabildiğimiz insan-sonrası durumda yaşam, tüm gerçekliği ile sanata da yön vermektedir. Varlığımızın yerkürenin gerçeğinden bağımsız bir kurguda mümkün olamayacağı kavrayışı ile temellenen teknolojinin açtığı alanlara kayan sanatın, gerçek olana dokunmayı esas edindiğinin altı çizilmelidir. Makale bahsi geçen alan değişimini belirlemek ve çözümlemek için yazılmıştır.

\section{Kaynakça}

Carroll,N. (1999). Philosophy Of Art, A Contemporary Introduction. Oxon, Great Britain: Routledge.

Foster, H. (1996). Gerçeğin Geri Dönüşü, Yüzyılın Sonunda Avangard. İstanbul: Ayrıntı Yayınları.

Gielen, P. (2016). Sanatsal Çokluğun Mirıltısı, Küresel Sanat, Siyaset, Postfordizm. İstanbul: Norgunk Yayınlar1.

Lovejoy, M. (2004). Digital Currents: Art In The Electronic Age. London: Routledge.

Negri, A. (2013). Sanat ve Çokluk. İstanbul: Monokl Yayınlar1.

Shanken, E.A. (2009). Art And Electronic Media. London: Phaidon

\section{Görsel Kaynaklar}

Görsel 1: Yönetmen Werner Herzog, Aile Saadeti Ltd. (Family Romance LLC.) Filmden Bir kesit, 2019. (https://fikrisinema.com/aile-saadeti/) Erişim Tarihi: 20.04.2021, 15:21.

Görsel 2: Ben Kinmont, 'Kirli Bulaşıklarını Yıkayacağım' (I Will Wash Your Dirty Dishes), Ben Kinmont'un Bir Katılımcının Evinde Bulaşık Yikarken Çekilen Anonim Fotoğrafi, Performans - Davranış Modeli, 1994.

(http://www.benkinmont.com/projects/ichwerde.h tm) Erişim Tarihi: 21.04.2021, 17:10
Görsel 3: Yönetmen Reha Erdem, 'Seni Buldum Ya', Uzun Metrajl1 Film, Filmden Bir Kesit, 2021. (https://bianet.org/bianet/yasam/240262-rehaerdem-den-yeni-filmi-seni-buldum-ya-dan-ilkfragman) Erişim Tarihi: 15.04.2021, 12:20

Görsel 4: Michael Mandiberg, Gerçek Maliyet (The Real Cost), Web Sitesi Eklentisi, Siteden Alınmış Bir Ekran Kesiti, 2006. (https://therealcosts.com) Erişim Tarihi: 09.03.2021, 13:35

Görsel 5: Kitt Galloway ve Sherrie Rabinowitz, 'Uzamda Delik' (Hole In Space), Bir Topluluk İletişim Heykeli (A Public Communication Sculpture), 1980. (https://www.researchgate.net/figure/KitGalloway-and-Sherrie-Rabinowitz-Hole-in-Space-APublic-Communication-Sculpture_fig8_313744281) Erişim Tarihi: $11.02 .2021,14: 43$

Görsel 6: Walter Schels, Ölümden Önce Yaşam (Life Before Death) Heiner Scmitz'in Portresi, Yaş: 52, İlk Portre 19 Kasım 2003, İkinci Portre 14 Aralık 2003. Portre Fotoğraf, 2003. (http://www.walterschels.com/en/portfolios/portr aits/album/8) Erişim Tarihi: 20.04.2021, 16:00 